УДК 579.26

DOI: $10.18101 / 2542-0623-2020-2-24-36$

\title{
РАСПРОСТРАНЕНИЕ ПРОТЕОЛИТИЧЕСКИХ БАКТЕРИЙ В ХОЛОДНЫХ ИСТОЧНИКАХ БУКСЫХЕН (СЕВЕРНОЕ ПРИБАЙКАЛЬЕ)
}

Т. Г. Банзаракцаева, Е. Ц. Дамбинова, Е. Л. Муруева, А. М. Биджоян, Е. В. Лаврентьева

\section{(C) Банзаракцаева Туяна Геннадьевна}

кандидат биологических наук, научный сотрудник, лаборатория микробиологии, Институт общей и экспериментальной биологии СО РАН Россия, 670047, г. Улан-Удэ, ул. Сахьяновой, 6 tuyana_banz@mail.ru

\section{(C) Дамбинова Екатерина Цыдыпжаповна}

инженер, лаборатория экологии и систематики животных, Институт общей и экспериментальной биологии СО РАН Россия, 670047, г. Улан-Удэ, ул. Сахьяновой, 6 ekaterina_dambina@gmail.com

\section{(C) Муруева Елена Леонидовна}

аспирант, лаборатория микробиологии, Институт общей и экспериментальной биологии СО РАН Россия, 670047, г. Улан-Удэ, ул. Сахьяновой, 6 elena.murueva38@mail.ru

\section{(C) Биджоян Арман Мурадович} магистрант, Институт общей и экспериментальной биологии СО РАН Россия, 670047, г. Улан-Удэ, ул. Сахьяновой, 6 armanbidzoan@gmail.com

\section{(C) Лаврентьева Елена Владимировна}

кандидат биологических наук, старший научный сотрудник, лаборатория микробиологии, Институт общей и экспериментальной биологии СО РАН Россия, 670047, г. Улан-Удэ, ул. Сахьяновой, 6 Бурятский государственный университет имени Доржи Банзарова Россия, 670000, г. Улан-Удэ, ул. Смолина, 24 а lena_1@mail.ru

Аннотация. В холодных источниках Буксыхен (Северное Прибайкалье) рассмотрено пространственно-временное распространение гетеротрофных бактерий, в частности протеолитической группы. Показано, что воды пяти выходов источников Буксыхен являются постоянно холодными, пресными и слабощелочными и относятся к гидрокарбонатному кальциевому типу. Сравнительный анализ не выявил сезонных изменений в распространении гетеротрофных бактерий. Численность аэробных и анаэробных протеолитических бактерий, независимо от типа пробы, была достаточно высокой и достигала 106 кл/мл. Впервые из источников Буксыхен-щитовидный и Буксыхенжелудочный выделены чистые культуры психротолерантных протеолитических 
факультативно-анаэробных бактерий родов Janthinobacterium и Yersinia, по предварительным данным, представляющие новые виды данных таксонов.

Ключевые слова: холодные источники; микробное сообщество; гетеротрофные бактерии; протеолитические бактерии; психрофильные и психротолерантные бактерии.

\section{Для цитирования}

Распространение протеолитических бактерий в холодных источниках Буксыхен (Северное Прибайкалье) / Т. Г. Банзаракцаева [и др.] // Природа Внутренней Азии. Nature of Inner Asia. 2020. № 2(15). С. 24-36.

DOI: $10.18101 / 2542-0623-2020-2-24-36$

\section{Введение}

Постоянно холодные экосистемы широко распространены на Земле. Около 85\% биосферы постоянно подвергается воздействию температур ниже $5^{\circ} \mathrm{C}$. Холодные обитания охватывают территории от Арктики до Антарктики, от высоких гор до глубин океана. Фундаментальные исследования показывают, что все эти экосистемы успешно колонизированы психрофильными микроорганизмами, способными процветать при низких температурах [Margesin, Miteva, 2011; Anesio et al. 2017; Boetius et al., 2015; Hotaling et al., 2017; Martin \& McMinn, 2018]. Эти микроорганизмы играют ключевую экологическую роль в их среде обитания и включают в себя большое разнообразие представителей всех трех доменов (бактерии, археи, эукариоты) [Margesin \& Miteva, 2011].

К настоящему времени исследования микробных сообществ наземных холодных источников были спорадическими [Rudolph et al., 2001, Camacho et al., 2005, Perreault et al., 2007; Perreault et al., 2008, Chaudhary et al., 2009, Zeng et al., 2010, $\mathrm{Li}$, et al., 2012]. Эти исследования показали, что в холодных источниках присутствуют в основном психротолерантные или психрофильные микробные сообщества с представителями Proteobacteria, Acidobacteria, Deinococci, Sphingobacteria, Flavobacteria, Nitrospirae, Actinobacteria, Gemmatimonadetes, архейные клоны были классифицированы как Crenarchaeota и Thaumarchaeota. Также было установлено, что видовое разнообразие микробных сообществ исследуемых источников схоже с сообществами других холодных местообитаний, таких как снег, лед и почвы высокогорий. Распространение гетеротрофных психрофильных бактерий в холодных источниках практически не изучалось. Тем не менее данная группа бактерий является потенциальными носителями различных ферментов, в том числе протеаз, устойчивых и активных при низких температурах, и может представлять биотехнологический интерес.

Целью данной работы было изучение пространственно-временного распространения протеолитических бактерий в микробных сообществах холодных источников Буксыхен (Северное Прибайкалье).

\section{Материалы и методы}

Объектами исследования были холодные источники Буксыхен (Северное Прибайкалье, $53^{\circ} 59^{\prime} 41.2 »$ с.ш., $110^{\circ} 02^{\prime} 00.9$ » в.д.). Источники Буксыхен расположены в 375 км от г. Улан-Удэ, недалеко от административной границы района (5 км от Баргузинского дацана) в 500 м от трассы у северо-западного борта Баргузинской 
впадины. Высота над уровнем моря 604 м. Источник представлен пятью выходами, которые берут начало из-под крутого скального выступа и сливаются в единый ручей. Каждый из пяти выходов имеет собственное название: глазной, щитовидный, сердечный, желудочный и печеночный. Четыре источника из пяти имеют активную разгрузку воды. Источник Буксыхен-глазной представляет собой небольшую воронку с водой, которая, вероятно, имеет низкий дебит и просачивается через грунты. Местные жители используют источники в бальнеологических целях.

Пробы воды и донных осадков для бактериологических исследований отбирали в стерильную посуду. До проведения анализов пробы хранили в темноте при температуре in situ или в холодильнике. В местах отбора проб температуру воды измеряли сенсорным электротермометром Prima (Португалия), кислотность среды (pH) - портативным pH-метром pHер2 (Португалия), значения общей минерализации - портативным тестер-кондуктометром TDS — 4 (Сингапур), $\mathrm{Eh}$ - измерителем редокс-потенциала ORP (Португалия).

Содержание карбонатов, гидрокарбонатов определяли титрованием [Резников и др., 1970]. Катионный и анионный состав воды определяли методом капиллярного электрофореза на системе «Капель-105М» (Россия) в ЦКП «Прогресс» ВСГУТУ (г. Улан-Удэ), сульфиды были определены колориметрическим методом на портативном фотоколориметре DR/890 (HACH, США). Микроэлементный состав донных осадков определен методом ИСП-МС на приборе высокого разрешения ELEMENT 2 фирмы Finnigan MAT в ЦКП ИГХ СО РАН (г. Иркутск).

Содержание органического углерода $\left(\mathrm{C}_{\text {орг }}\right)$ в пробах определяли по методу Тюрина в модификации Никитина (Аринушкина, 1970).

Учет численности психрофильных гетеротрофных жизнеспособных клеток микроорганизмов проводили методом 10-кратных разведений на среде Пфеннига с добавлением $1,5 \%$ пептона в качестве субстрата. Культивирование психрофильных бактерий проводили в аэробных и анаэробных условиях при температуре $5-7^{\circ} \mathrm{C}$.

Для выделения чистых культур аэробных протеолитических бактерий на твердой среде использовали метод Коха с последующим применением метода истончающегося штриха. Для выделения чистых культур анаэробных протеолитиков проводили посев на агаризованную среду в чашках Петри и помещали их в анаэростаты, предварительно откачав воздух, и закачивали в них азот. Культивирование проводили при температуре $5-7^{\circ} \mathrm{C}$ в течение 7-14 дней, в промежутках повторно продували анаэростаты азотом.

В результате последовательных пересевов единичных колоний с твердой среды на жидкую среду были получены чистые культуры психроактивных протеолитических микроорганизмов.

Для определения оптимальных условий роста выделенных бактерий использовали основную среду для каждого штамма. Температурный диапазон роста определяли по удельной скорости роста при температурах от 5 до $42^{\circ} \mathrm{C}$. Диапазон и оптимум солености - по скорости роста при различных концентрациях $\mathrm{NaCl}$ (0-20 г/л). Влияние $\mathrm{pH}$ среды на скорость роста определяли, культивируя клетки при оптимальной температуре и солености на основной среде для роста при различных значениях $\mathrm{pH}$. 


\section{Результаты и обсуждение}

Функционирование микробного сообщества зависит от множества факторов среды обитания. Основными физико-химическими показателями для деятельности микроорганизмов являются температура, $\mathrm{pH}$, общая минерализация, доступность кислорода и т. д., которые были определены в местах проведения исследований и отбора проб в июле 2014 г. и декабре 2016 г. В зимний период в источнике Буксыхен-глазной отбор проб воды не производился в связи с отсутствием проточной воды.

Исследуемые источники характеризуются постоянно низкой температурой воды, слабощелочными значениями $\mathrm{pH}$ и низкой минерализацией независимо от сезона (табл. 1). Сезонные исследования гидрохимических показателей в других холодных источниках нашего региона также показывают стабильность данных параметров [Ульзетуева, Хахинов, 2011]. Все источники имели положительные значения редокс-потенциала. Вода источника Буксыхен-глазной в летнее время имела более высокую температуру $\left(7,4{ }^{\circ} \mathrm{C}\right)$ и более окисленные условия относительно других выходов источника, что связано с низким дебитом воды и более застойными условиями в воронке с водой.

Таблица 1

Физико-химическая характеристика исследуемых источников

\begin{tabular}{|c|c|c|c|c|c|}
\hline Источник & Сезон & $\mathbf{T},{ }^{\circ} \mathbf{C}$ & pH & Eh, MB & М, мг/дм ${ }^{3}$ \\
\hline \multirow[t]{2}{*}{ Бук-глазной } & летний & 7,4 & 8,09 & 210 & 62 \\
\hline & зимний & - & - & - & - \\
\hline \multirow[t]{2}{*}{ Бук-щитовидный } & летний & 4,5 & 8,03 & 161 & 51 \\
\hline & зимний & 3,9 & 8,6 & 142 & 55 \\
\hline \multirow[t]{2}{*}{ Бук-сердечный } & летний & 4,5 & 8,16 & 151 & 51 \\
\hline & зимний & 3,8 & 8,42 & 155 & 49 \\
\hline \multirow[t]{2}{*}{ Бук-желудочный } & летний & 4,2 & 8,34 & 135 & 52 \\
\hline & зимний & 3,5 & 8,28 & 145 & 68 \\
\hline \multirow[t]{2}{*}{ Бук-печеночный } & летний & 4,2 & 8,29 & 134 & 55 \\
\hline & зимний & 3,5 & 8,43 & 146 & 51 \\
\hline
\end{tabular}

М - минерализация «-» - не определено

Макрокомпонентный и микрокомпонентный анализ проводили в пробах летнего периода. Анализ катионного состава воды выявил преобладание ионов кальция, их содержание варьировало от 460 до 548 мг/дм³ (табл. 2). Содержание ионов калия не превышало 5,36 мг/дм³ , натрия - 2,98 мг/дм³. Преобладающим анионом в воде источников были гидрокарбонат-ионы, их концентрация достигала 548 мг/дм³. Карбонат-ионы не были зафиксированы, что характерно для вод с низкой щелочностью. Проведенный анализ содержания ионов сульфида в водах исследуемого источника показал их отсутствие. Определение органического углерода в осадках выявило их низкую концентрацию $(0,23-0,54 \%)$, что, вероятно, связано со структурой осадков. Осадки в основном были представлены смесью камней и песка. 
Ионный состав воды (мг/дм3) и содержание органического углерода в осадках (\%) источников Буксыхен

\begin{tabular}{|l|l|l|l|l|l|}
\hline Элементы & Бук-гл. & Бук-щит. & Бук-серд. & Бук-желуд. & Бук-печ. \\
\hline $\mathrm{K}^{+}$ & 5,36 & 5,34 & 4,70 & 5,06 & 5,22 \\
\hline $\mathrm{Na}^{+}$ & 2,98 & 2,90 & 2,46 & 2,61 & 2,51 \\
\hline $\mathrm{Mg}^{2+}$ & 6,10 & 6,13 & 5,17 & 5,54 & 5,32 \\
\hline $\mathrm{Ca}^{2+}$ & 517 & 548 & 460 & 509 & 500 \\
\hline $\mathrm{HCO}_{3}^{-}$ & 56 & 45 & 46 & 47 & 49 \\
\hline $\mathrm{CO}_{3}^{2-}$ & н.о. & н.о. & н.о. & н.о. & н.о. \\
\hline $\mathrm{Cl}^{-}$ & 0.199 & 0,173 & 0,121 & 0,164 & 0,152 \\
\hline $\mathrm{S}^{-}$ & н.о. & н.о. & н.о. & н.о. & н.о. \\
\hline $\mathrm{SO}_{4}{ }^{2-}$ & 4,09 & 4,07 & 3,85 & 3,87 & 3,95 \\
\hline $\mathrm{NO}_{3}{ }^{2-}$ & 0,182 & 0,822 & 0,251 & 0,476 & 0,664 \\
\hline $\mathrm{F}^{-}$ & 0,309 & 0,284 & 0,269 & 0,279 & 0,265 \\
\hline $\mathrm{PO}_{4}{ }^{3-}$ & 0,222 & 0,111 & 0,118 & 0,0963 & 0,105 \\
\hline $\mathrm{C}_{\text {arr }}$ & 0,35 & 0,23 & 0,27 & 0,5 & 0,54 \\
\hline
\end{tabular}

н. о. - не обнаружено

Таким образом, наши исследования физико-химических параметров показали, что воды источника Буксыхен являются холодными, пресными (до 0,1 г/л), слабощелочными. По анионному составу воды этих источников являются гидрокарбонатными, а по катионному — кальциевыми.

Также был изучен микроэлементный состав донных осадков, было определено более 50 элементов, в таблице представлены элементы с концентрацией выше 10 мг/кг (табл. 3). Полученные результаты показали, что в целом содержание всех элементов не превышало кларковые значения для поверхности земной коры.

В воде источников Буксыхен был проведен подсчет общего микробного числа. Наиболее высокая общая микробная численность (ОМЧ) была выявлена в пробе Бук-глазной (120 625 кл/мл), в остальных пробах ОМЧ было на порядок ниже, и минимальное значение было обнаружено в пробе Бук-печеночный (15 010 кл/мл). Максимальное число микробных клеток в воде пробы Бук-глазной, вероятно, связано опять же с низким дебитом источника, что обусловливает увеличение концентрации бактериальных клеток. Полученные результаты сопоставимы с данными других исследователей в холодных морских местообитаниях, так, численность микроорганизмов в арктических водах в среднем достигает $10^{5}-10^{6}$ клеток/мЛ [Brinkmeyer et al., 2003; Gerdes et al., 2005; Harder, 2009].

Проведен первичный микробиологический анализ воды и осадков исследуемых источников с целью определения в этих образцах психрофильных бактерий различных физиологических групп. Полученные результаты показали, что в воде источников Буксыхен активно развиваются психрофильные аэробные и анаэробные гетеротрофы (до $10^{7}$ кл/мл) и отсутствуют сульфатредукторы, метаногены, ацетогены и железоредукторы, культивирующиеся при $7^{\circ} \mathrm{C}$. 
Т. Г. Банзаракиаева, Е. Ц. Дамбинова, Е. Л. Муруева, А. М. Биджоян, Е. В. Лаврентьева.

Распространение протеолитических бактерий в холодных источниках Буксыхен (Северное Прибайкалье)

Таблица 3

Микроэлементный состав донных осадков источников Буксыхен, $>10$ мг/кг

\begin{tabular}{|l|l|l|l|l|l|}
\hline Элемент & Бук-гл. & Бук-щит. & Бук-серд. & Бук-желуд. & Бук-печ. \\
\hline $\mathrm{Ti}$ & 5623 & 7098 & 5095 & 5352 & 4256 \\
\hline $\mathrm{V}$ & 146 & 188 & 163 & 160 & 116 \\
\hline $\mathrm{Mn}$ & 859 & 961 & 846 & 854 & 631 \\
\hline $\mathrm{Cu}$ & 65 & 82 & 28 & 107 & 142 \\
\hline $\mathrm{Zn}$ & 317 & 228 & 140 & 458 & 205 \\
\hline $\mathrm{Sr}$ & 1232 & 1228 & 1568 & 1627 & 1242 \\
\hline $\mathrm{Zr}$ & 200 & 152 & 266 & 128 & 139 \\
\hline $\mathrm{Ba}$ & 844 & 723 & 569 & 703 & 930 \\
\hline $\mathrm{Cr}$ & 19 & 20 & 22 & 20 & 14.4 \\
\hline $\mathrm{Ni}$ & 67 & 39 & 15 & 63 & 31 \\
\hline $\mathrm{Ga}$ & 19 & 20 & 19 & 20 & 20 \\
\hline $\mathrm{Rb}$ & 46 & 41 & 31 & 30 & 55 \\
\hline $\mathrm{La}$ & 35 & 36 & 24 & 43 & 27 \\
\hline $\mathrm{Ce}$ & 66 & 72 & 46 & 81 & 50 \\
\hline $\mathrm{Nd}$ & 32 & 36 & 25 & 37 & 24 \\
\hline
\end{tabular}

Учет численности аэробных и анаэробных гетеротрофов в пробах воды летнего и зимнего периодов не выявил сезонной динамики (рис. 1, 2). В зимний период в источнике Буксыхен-глазной разгрузка воды не происходила, в связи с чем количественный анализ распространения гетеротрофных бактерий не был осуществлен.

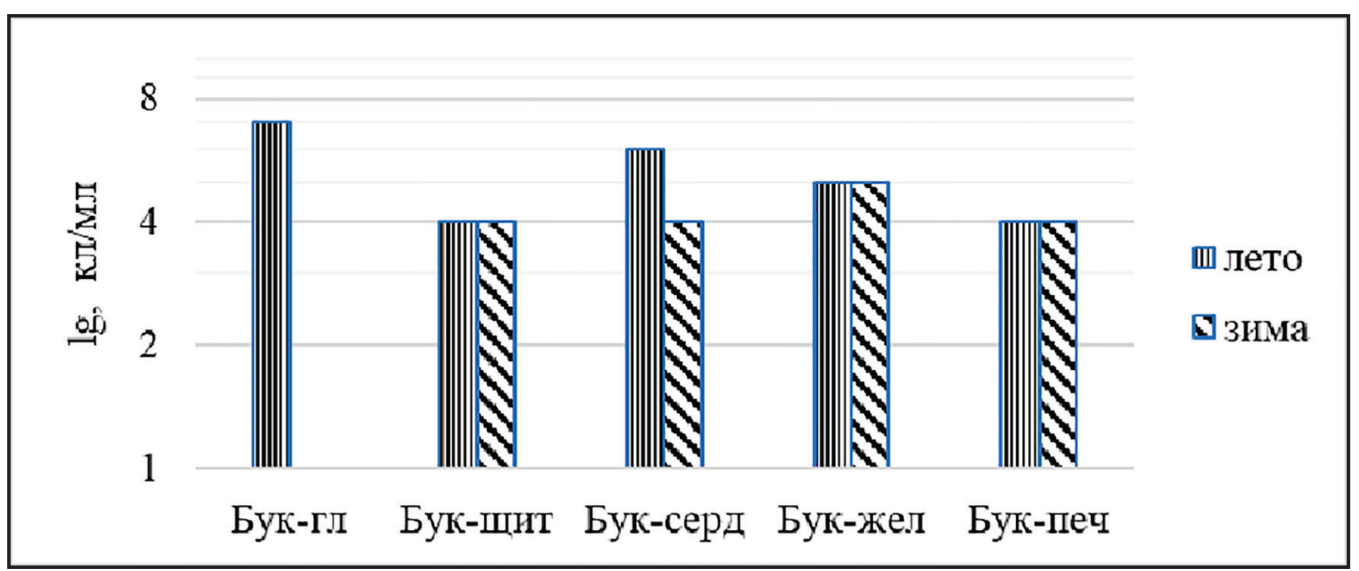

Puc. 1. Численность гетеротрофных аэробных бактерий в воде по сезонам 


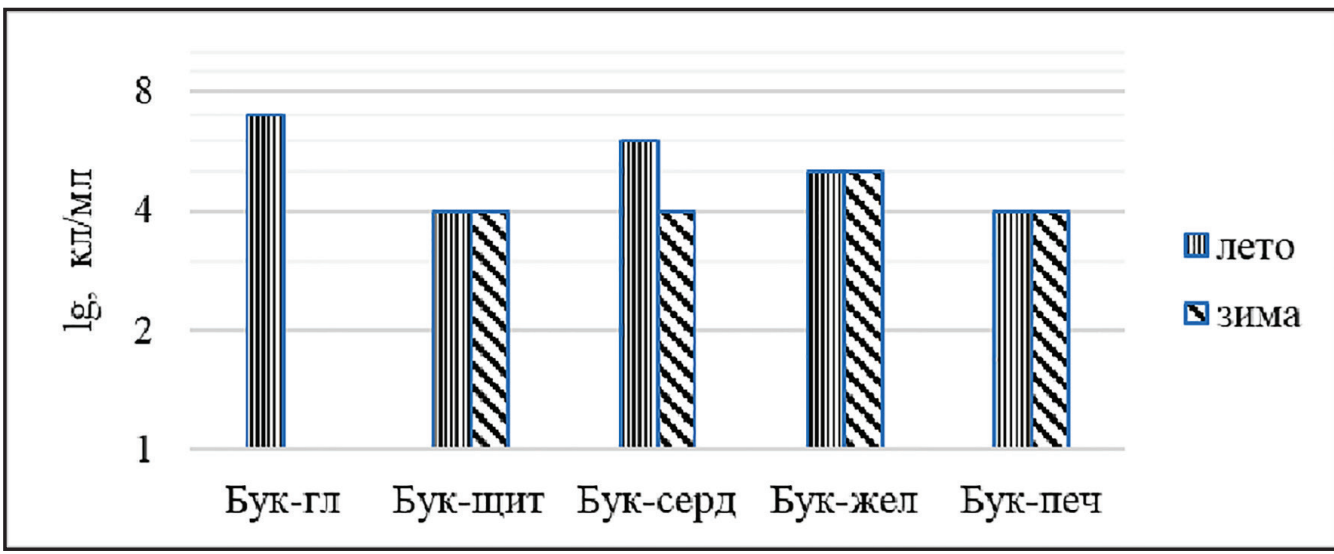

Puc. 2. Численность гетеротрофных анаэробных бактерий в воде по сезонам

Была определена численность аэробных и анаэробных протеолитических бактерий в пробах воды и осадков исследуемых выходов источника Буксыхен. Учет аэробных протеолитических бактерий в воде показал их распространение во всех выходах от $10^{5}$ до $10^{6}$ кл/мл. В осадках также максимальное число аэробных протеолитиков достигало $10^{6}$ кл/мл (выход Буксыхен «желудочный», «сердечный» и «глазной»). В пробах четырех источников из пяти численность анаэробных клеток в воде составила $10^{5}$ кл/мл, исключением был источник Бук-глазной, здесь число анаэробных протеолитиков было на порядок ниже. Минимум протеолитических бактерий наблюдали в пробах осадка Бук-щитовидный — $10^{4}$ кл/мл (табл. 4).

\section{Таблица 4}

Численность протеолитических бактерий в источниках Буксыхен, кл/мл

\begin{tabular}{|l|l|l|l|l|}
\hline \multirow{2}{*}{\multicolumn{1}{c|}{ Источник }} & \multicolumn{2}{c|}{ Аэробы } & \multicolumn{2}{c|}{ Анаэробы } \\
\cline { 2 - 6 } & \multicolumn{2}{|c|}{ Вода } & \multicolumn{1}{c|}{ Осадки } & \multicolumn{2}{c|}{ Вода } & \multicolumn{1}{c|}{ Осадки } \\
\hline Бук-глазной & $10^{6}$ & $10^{6}$ & $10^{4}$ & $10^{5}$ \\
\hline Бук-щитовидный & $10^{6}$ & $10^{5}$ & $10^{5}$ & $10^{4}$ \\
\hline Бук-сердечный & $10^{6}$ & $10^{6}$ & $10^{5}$ & $10^{5}$ \\
\hline Бук-желудочный & $10^{5}$ & $10^{6}$ & $10^{5}$ & $10^{6}$ \\
\hline Бук-печеночный & $10^{5}$ & $10^{5}$ & $10^{5}$ & $10^{6}$ \\
\hline
\end{tabular}

Были выделены и получены накопительные и чистые культуры анаэробных и факультативно-анаэробных психрофильных и психроактивных бактерий, и были изучены их некоторые физиолого-биохимические свойства. Для выделения чистых культур пептолитических микроорганизмов был использован метод анаэробного культивирования [Hungate, 1969] на твердых средах и отобраны 24 штамма. После пересева в жидкую среду штаммы были сгруппированы по родам с использованием метода MALDI масс-спектрометрии целых клеток. В результате проведенного анализа полученные штаммы протеолитических бактерий были разделены 
на 7 групп: штаммы 1-7 отнесены к виду Janthinobacterium lividum; штаммы $8,10,11,15$ и 16 - к виду Yersinia enterocolitica; штаммы 9, 12, 13 и 20 - к виду Y. bercovieri; штаммы 14, 17, 18 и 24 - к виду Y. aleksieciae; штамм 21 - к виду Lactobacillus saerimneri; штамм 22 - к виду Bacillus funiculus; штамм 23 - к виду Achromobacter insolitus.

Из каждой группы штаммов были отобраны по одному представителю и выполнены секвенсы генов $16 \mathrm{~S}$ рРНК с универсальным бактериальным праймером 27F. Филогенетический анализ полученных последовательностей показал, что 2 штамма генетически отдалены от известных видов и, вероятно, представляют собой новые таксоны.

Нами получен полный сиквенс последовательности гена $16 \mathrm{~S}$ рРНК штаммов Buc-1 и Buc-16. Филогенетический анализ полученных последовательностей показал, что оба штамма генетически отдалены от известных видов и, вероятно, представляют собой новые таксоны. Для штаммов 1 и 16 были получены почти полные последовательности длиной 1398 и 1411 п. н. соответственно (рис. 3). Филогенетический анализ с помощью базы данных GenBank и программы BLAST показал, что близкородственным видом для штамма Buc-1 являются J. lividum со сходством 99,4\%, штамму Вuc-16 родственен вид $Y$. aldovae и $Y$. pekkanenii со сходством 99,7\%. Филогенетическая дендрограмма была построена с использованием пакета программ MEGA X [Tamura et al., 2013, Kumar et al, 2018] с применением метода поиска ближайших соседей («neibour-joining») [Saitou and Nei., 1987].

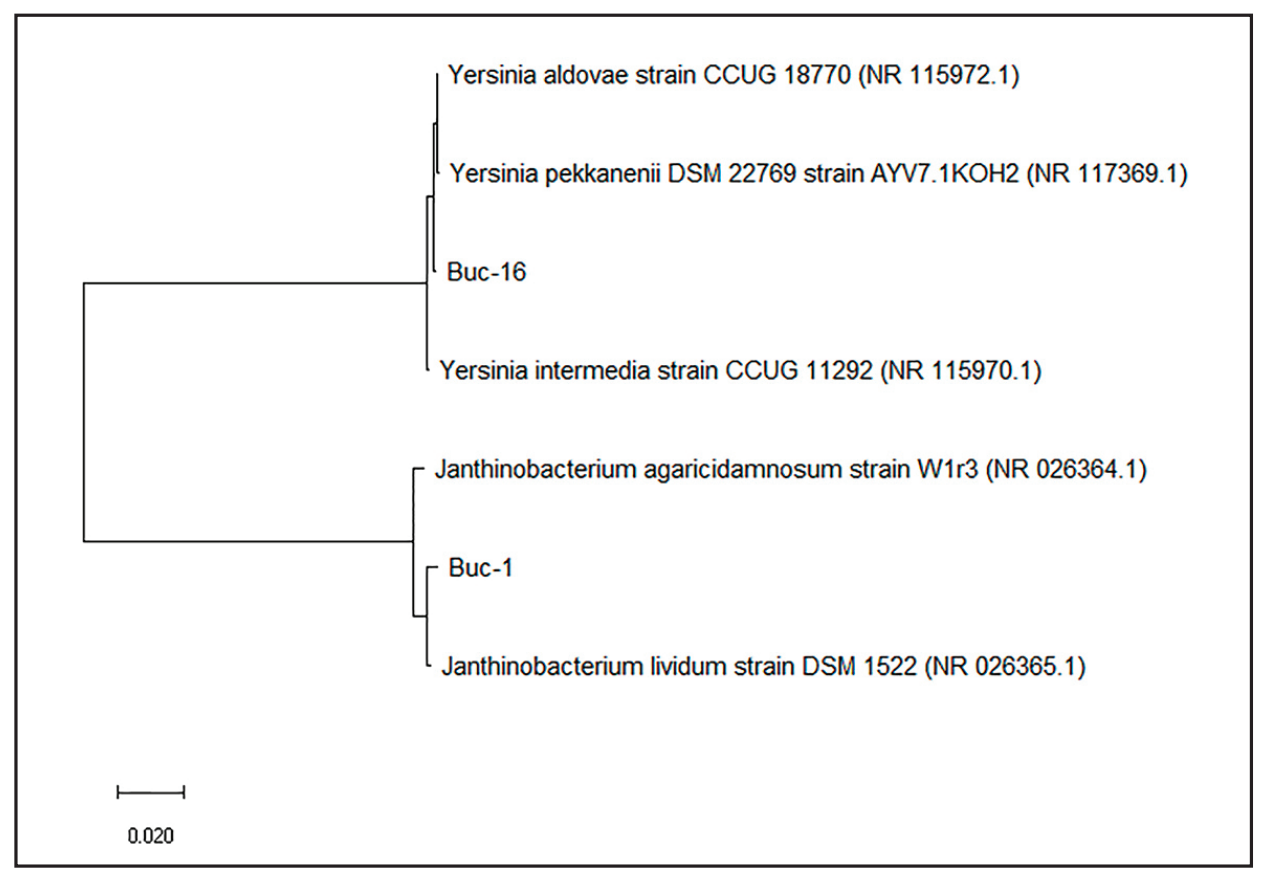

Puc. 3. Филогенетическая дендрограмма, построенная на основе анализа нуклеотидных последовательностей генов 16S рРНК. Длина масштабной линейки: 2 замены на 100 нуклеотидов. Учетный номер базы данных NCBI указан в скобках. Дендрограмма построена с использованием метода поиска ближайших соседей (“neibour-joining”) 
В результате работы также были получены чистые культуры психроактивных анаэробных гидролитических бактерий на казеине (18 штаммов), желатине (12 штаммов), сахарозе (10 штаммов) и Tween-80 (11 штаммов). Микроскопические исследования выявили в них палочки, отличающие размером, подвижностью и спорообразованием.

\section{Характеристика штамма Вис-1}

Получен из накопительной культуры на среде Пфеннига с донным осадком источника Буксыхен-желудочный. По данным анализа, $16 \mathrm{~S}$ рРНК относится к роду Janthinobacterium, близок виду Janthinobacterium lividum. Эти микроорганизмы относятся к бета-протеобактериям порядка Bukholderiales и семейству Oxalobacteriaceae. Являются грамотрицательными факультативно-анаэробными бактериями, обитающими в низкотемпературных экосистемах [Shivaji et al., 1991; Brambilla et al., 2001; Schloss et al. 2010]. Штамм Вuc-1 на агаризованной среде образовывал круглые гладкие блестящие колонии размером до 4 мм. Его клетки представляли собой подвижные палочки длиной от 2 до 6 мкм. Культура выделена в анаэробных условиях, но может расти и аэробно.

Характеристика штамма Вис-16

Получен из накопительной культуры на среде Пфеннига с донным осадком источника Буксыхен-щитовидный. По данным MALDI масс-спектрометрии целых клеток и филогенетического анализа последовательностей генов, $16 \mathrm{~S}$ pРНК относится к роду Yersinia, принадлежащему ветви Gammaproteobacteria, порядку Enterobacteriales и семейству Enterobacteriaceae и наиболее близок к видам Y. aldovae и Y. pekkanenii. Это грамотрицательные факультативно-анаэробные бактерии, часто обнаруживающиеся в желудочно-кишечном тракте животных. На агаризованной среде штамм Bush-16 образовывал круглые гладкие блестящие с ровным краем колонии диаметром 1-2 мм. Клетки новых бактерий представляли собой неподвижные палочки, напоминающие фитильки. Культура выделена при $7{ }^{\circ} \mathrm{C}$ в анаэробных условиях, но может расти и аэробно.

Исследование экофизиологии выделенных культур протеолитиков из холодных источников показало, что они способны развиваться в широком диапазоне температур $\left(7-42^{\circ} \mathrm{C}\right)$, солености и $\mathrm{pH}(4-10)$.

Штамм Вuс-1 рос при температуре от 7 до $42{ }^{\circ} \mathrm{C}$ с оптимумом при $29{ }^{\circ} \mathrm{C}$ и, соответственно, является психротолерантным мезофиллом (рис. 4). Температурный диапазон роста для выделенного штамма Buc-16 составлял от 7 до $42{ }^{\circ} \mathrm{C}$ с оптимумом при $20^{\circ} \mathrm{C}$. Таким образом, выделенный штамм является факультативным психрофилом.

Изучение роста исследуемых культур в градиенте $\mathrm{pH}$ показал, что все культуры способны накапливать биомассу в диапазоне рН от 5 до 10 (рис. 5). Оптимальное значение для штамма Buc-1 является $\mathrm{pH}$ 7. Для штамма Buc-16 максимальный рост наблюдался при $\mathrm{pH} 7$ и 8 . Таким образом, исследуемые культуры относятся к нейтрофильным микроорганизмам по отношению к $\mathrm{pH}$.

Изучение ростовых характеристик исследуемых штаммов при различных концентрация $\mathrm{NaCl}$ показало, что штамм Buc-1 имел максимальный рост при концентрации хлорида натрия 2,5 г/л (рис. 6). Штамм Вuс-16 демонстрировал наименьшие показатели роста во всем диапазоне, но при концентрации 10 г/л накопил достаточно высокую биомассу. Исследования показали, что, несмотря на 
Т. Г. Банзаракиаева, Е. Ц. Дамбинова, Е. Л. Муруева, А. М. Биджоян, Е. В. Лаврентьева.

Распространение протеолитических бактерий в холодных источниках Буксыхен (Северное Прибайкалье)

пресноводное местообитание изучаемых культур - холодные источники Буксыхен, эти бактерии имеют достаточно высокий потенциал и способны развиваться и при более высоких концентрациях хлорида натрия.

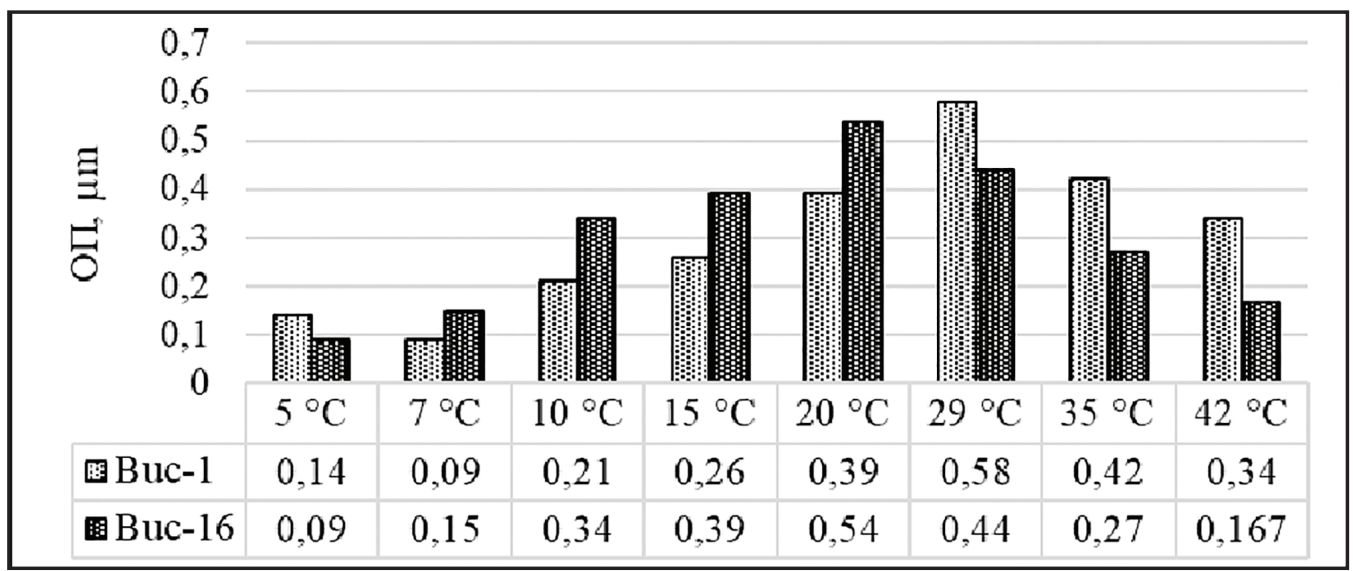

Puc. 4. Зависимость роста культур Вuс-1 и Вuс-16 от температуры

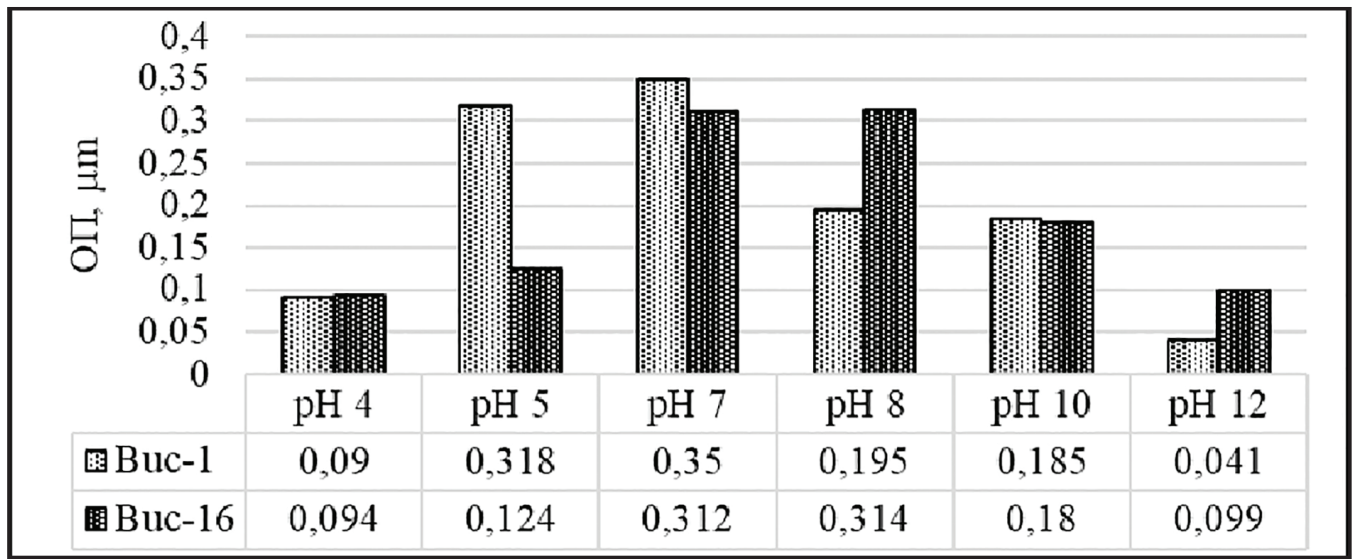

Рuc. 5. Зависимость роста культур Вuс-1 и Вuс-16 от $\mathrm{pH}$

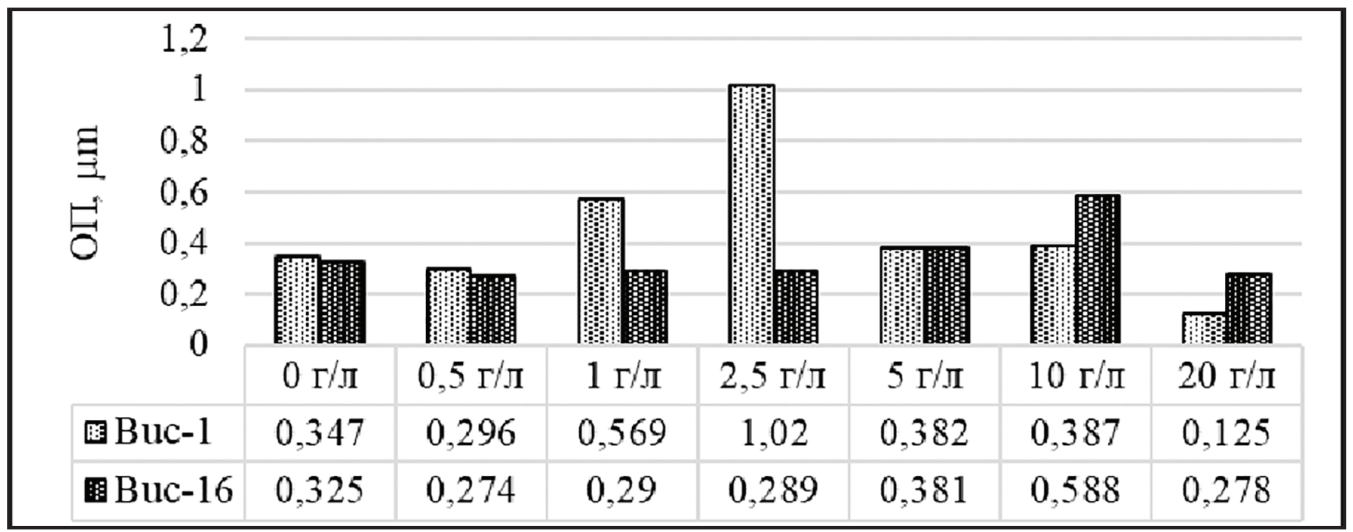

Puс. 6. Зависимость культур Вuc-1 и Вuc-16 от концентраций $\mathrm{NaCl}$ 


\section{Заключение}

Исследуемые источники Буксыхен являются постоянно холодными пресными и слабощелочными. Температура воды не превышала $7,4{ }^{\circ} \mathrm{C}$, минерализация воды в источниках была менее 1 г/л, pН воды был в пределах 8,03-8,6. По химическому составу воды исследуемых источников гидрокабонатные кальциевые. Эти воды представляют ценность как нативные пресные, которые могут употребляться для питья и приготовления пищи, для целей розлива без специальной реагентной водоподготовки. Изучение сравнительной характеристики сезонных изменений физико-химических параметров не выявило значительных различий, что свидетельствует о стабильности экосистемы источников Буксыхен.

Микробиологические исследования показали широкое пространственновременное распространение гетеротрофных психрофильных и психротолерантных бактерий в источниках Буксыхен. Общая микробная численность в воде была сопоставима с результатами исследований в холодных морских местообитаниях. Анализ численности аэробных и анаэробных протеолитических бактерий в воде и донных осадках исследуемых источников выявил их высокую численность при температуре культивирования 5-7 ${ }^{\circ} \mathrm{C}$. Впервые из источников Буксыхенщитовидный и Буксыхен-желудочный выделены чистые культуры психротолерантных протеолитических факультативно-анаэробных бактерий родов Janthinobacterium и Yersinia, по предварительным данным, представляющие новые виды данных таксонов. Исследование экофизиологии выделенных культур протеолитиков из холодных источников показало, что они способны развиваться в широком диапазоне температур $\left(7-42^{\circ} \mathrm{C}\right)$ и $\mathrm{pH}(4-10)$. Также было установлено, что, несмотря на пресноводное местообитание изучаемых культур, эти бактерии имеют достаточно высокий потенциал и способны развиваться и при более высоких концентрациях хлорида натрия.

Таким образом, полученные нами результаты показали, что в холодных источниках Буксыхен развивается и функционирует микробное сообщество, представленное различными таксономическими группами бактерий. В исследуемых микробных сообществах широко распространенны гетеротрофные бактерии, представляющие деструкционное звено в экосистеме источников, и они метаболически активны при пониженной температуре.

\section{Литература}

1. Аринушкина Е. В. Руководство по химическому анализу почв. М.: Изд-во Моск. ун-та, $1970.488 \mathrm{c}$.

2. Ульзетуева И. Д., Хахинов В. В. Гидрохимическая характеристика минеральных источников Юго-Западного Забайкалья // Водные ресурсы. 2011. Т. 38, № 5. С. 585-592.

3. Anesio A. M., Lutz S., Chrismas N. A. M., Benning L. G. The microbiome of glaciers and ice sheets // NPJ Biofilms Microbiomes. 2017. V. 3, № 10. DOI:10.1038/s41522-017-0019-0

4. Boetius A., Anesio A. M., Deming J. W., Mikucki J. A., Rapp J. Z. Microbial ecology of the cryosphere: sea ice and glacial habitats // Nat. Rev. Microbiol. 2015. V. 13, № 11. Pp. $677-$ 690. doi: $10.1038 /$ nrmicro3522

5. Brambilla E. et al. 16S rDNA diversity of cultured and uncultured prokaryotes of a mat sample from Lake Fryxell, McMurdo Dry Valleys, Antarctica // Extremophiles. 2001. V. 5, № 1. Pp. 23-33.

6. Brinkmeyer R., Knittel K., Jürgens J., Weyland H., Amann R. Helmke E. Diversity and Structure of Bacterial Communities in Arctic versus Antarctic Pack Ice // Applied and environmental microbiology. 2003. V. 69. Pp. 6610-6619. doi:10.1128/AEM.69.11.6610-6619.2003. 
7. Camacho A., Rochera C., Silvestre J. José, Vicente E., Hahn M. W. Spatial Dominance and Inorganic Carbon Assimilation by Conspicuous Autotrophic Biofilms in a Physical and Chemical Gradient of a Cold Sulfurous Spring: The Role of Differential Ecological Strategies // Microbial ecology. 2005. V. 50. Pp. 172-184. doi:10.1007/s00248-004-0156-x

8. Chaudhary A., Haack Sh. K., Duris J. W., Marsh T.L. Bacterial and Archaeal Phylogenetic Diversity of a Cold Sulfur-Rich Spring on the Shoreline of Lake Erie, Michigan // Applied and Environmental Microbiology. 2009. V. 75, № 15. Pp. 5025-5036. doi:10.1128/AEM.00112-09

9. Gerdes B., Brinkmeyer R., Dieckmann G., Helmke E. Influence of crude oil on changes of bacterial communities in Arctic sea-ice // FEMS Microb. Ecol. 2005. V. 53, № 1. Pp. 129-139.

10. Hungate R. E. A roll tube method for cultivation of strict anaerobes // In: Methods in microbiology 13. Eds. Norris J. R., Ribbons D. W. New York: Acad. 1969. V. 1. P. 117.

11. Harder T. Marine epibiosis: concepts, ecological consequences and host defence // Mar. Indust. Biofouling. 2009. V. 4. Pp. 219-231.

12. Hotaling S., Finn D. S., Joseph Giersch J., Weisrock D. W., Jacobsen D. Climate change and alpine stream biology: progress, challenges, and opportunities for the future // Biol Rev Camb Philos Soc. 2017. V. 92. № 4. Pp. 2024-2045. doi:10.1111/brv.12319

13. Kumar S., Stecher G., Li M., Knyaz C., and Tamura K. MEGA X: Molecular Evolutionary Genetics Analysis across computing platforms // Molecular Biology and Evolution. 2018. V. 35. Pp. 1547-1549.

14. Li G.H., Jiang W., Hou S. Wang L., Huang H., Ren S., Deng H., Dong. Microbial diversity in two cold springs on the Qinghai-Tibetan Plateau // Geosci. Front. 2012. V. 3. Pp. 317-325. doi:10.1016/j.gsf.2011.12.004.

15. Margesin R., Miteva V. Diversity and ecology of psychrophilic microorganisms // Res. Microbiol. 2011. V. 162, № 3. Pp. 346-361. doi:10.1016/j.resmic.2010.12.004

16. Martin A., McMinn A. Sea ice, extremophiles and life on extra-terrestrial ocean worlds // Int. J. Astrobiol. 2018. V. 17, № 1. Pp. 1-16.

17. Perreault N. N., Andersen D. T., Pollard W. H., Greer C. W., Whyte L. G. Characterization of the prokaryotic diversity in cold saline perennial springs of the Canadian high Arctic // Applied and environmental microbiology. 2007. V. 73, № 5. Pp. 1532-1543. doi.org/10.1128/ AEM.01729-06

18. Perreault N. N., Greer C. W., Andersen D. T., Tille S., Lacrampe-Couloume G., Lollar B. Sh., Whyte, L. G. Heterotrophic and Autotrophic Microbial Populations in Cold Perennial Springs of the High Arctic // Applied and Environmental Microbiology. 2008. V. 74. Pp. 68986907. doi:10.1128/AEM.00359-08

19. Rudolph C, Wanner G, Huber R. Natural communities of novel archaea and bacteria growing in cold sulfurous springs with a string-of-pearls-like morphology // Applied and Environmental Microbiology. 2001 V. 67, №. 5. Pp. 2336-2344. doi:10.1128/aem.67.5.23362344.2001.

20. Saitou N. and Nei M. The neighbor-joining method: A new method for reconstructing phylogenetic trees // Molecular Biology and Evolution. 1987. V. 4. Pp. 406-425.

21. Shivaji S. Ray, M. K., Kumar, G. S., Reddy G. S. N., Saisree L., Wynn-Williams D. D. Identification of Janthinobacterium lividum from the soils of the islands of Scotia Ridge and from Antarctic peninsula // Polar biology. 1991. V. 11, № 4. Pp. 267-271.

22. Schloss P. D., Allen H. K., Klimowicz A. K., Mlot C., Gross J.A., Savengsuksa S., McEllin J., Clardy J., Ruess R. W., Handelsman J. Psychrotrophic strain of Janthinobacterium lividum from a cold Alaskan soil produces prodigiosin // DNA and cell biology. 2010. V. 29. №. 9. $\mathrm{Pp}$. 533-541.

23. Tamura K., Nei M., and Kumar S. Prospects for inferring very large phylogenies by using the neighbor-joining method // Proceedings of the National Academy of Sciences (USA). 2004. V. 101. Pp. 11030-11035. 


\section{DISTRIBUTION OF PROTEOLYTIC BACTERIA IN BUKSYKHEN COLD SPRINGS} (NORTHERN BAIKAL REGION)

T. G. Banzaraktsaeva, E. Ts. Dambinova, E. L. Murueva, A. M. Bidzhoyan, E. V. Lavrentieva

Tuyana G. Banzaraktsaeva

Cand. Sci. (Biol.), Researcher, Laboratory of Microbiology,

Institute of General and Experimental Biology SB RAS

6 Sakhyanovoy St., Ulan-Ude 670047, Russia

tuyana_banz@mail.ru

\section{Ekaterina Ts. Dambinova}

Engineer, Laboratory of Animal Ecology and Taxonomy, Institute of General and Experimental Biology SB RAS

6 Sakhyanovoy St., Ulan-Ude 670047, Russia

ekaterina_dambina@gmail.com

Elena L. Murueva

Research Assistant, Laboratory of Microbiology, Institute of General and Experimental Biology SB RAS

6 Sakhyanovoy St., Ulan-Ude 670047, Russia

E-mail: elena.murueva38@mail.ru

Arman M. Bidzhoyan

Cand. for a Master's Degree,

Institute of General and Experimental Biology SB RAS

6 Sakhyanovoy St., Ulan-Ude 670047, Russia

armanbidzoan@gmail.com

Elena $V$. Lavrentyeva

Cand. Sci. (Biol.), Senior Researcher, Laboratory of Microbiology, Institute of General and Experimental Biology SB RAS

6 Sakhyanovoy St., Ulan-Ude 670047, Russia

Dorzhi Banzarov Buryat State University

24a Smolina St., Ulan-Ude 670000, Russia

lena_1@mail.ru

Abstract. The article considers the spatiotemporal distribution of heterotrophic bacteria, in particular, the proteolytic group of bacteria in Buksykhen cold springs (Northern Baikal Region). It was found that the waters of the five outlets of Buksykhen springs are constantly cold, fresh and midly alkaline and belong to the hydrocarbonate calcium type. A comparative analysis did not revealed seasonal changes in the distribution of heterotrophic bacteria. The number of aerobic and anaerobic proteolytic bacteria, regardless of the type of sample, was quite high and reached 106 cells $/ \mathrm{ml}$. For the first time we isolated pure cultures of psychrotolerant proteolytic facultative anaerobic bacteria of Janthinobacterium and Yersinia genera from the Buksykhen-thyroid and Buksykhen-gastric springs, early indications suggest that they represent new species of these taxa.

Keywords: cold springs; microbial community; heterotrophic bacteria; proteolytic bacteria; psychrophilic and psychrotolerant bacteria. 